\title{
Women's Political Representation in the Czech Republic in the context of the transition from Communism to Democracy ${ }^{1}$
}

\begin{abstract}
This paper gives an overview of women's political representation in Czechoslovakia and the Czech Republic after the fall of the iron curtain, framed in the context of the transition from Communism to democracy. It is concerned with both continuity and discontinuity between the old and the new regime regarding the political engagement of women - the persistence of traditional family model and gender stereotypes on one hand, and the radically changed roles of the private and the public sphere on the other. It focuses on the mechanisms disadvantaging women in their access to political power and on public attitudes to the measures which could level the playing field, namely gender quotas for political party candidate lists.
\end{abstract}

Key words: women, political participation, gender, quotas, elections, Czech Republic, Communism

n the last 25 years, the representation of women in institutionalized Czech politics has been considerably lower than that of men. The percentage of women in Czech governments has been fluctuating widely, from 0\% (1992-1996 and 1998-2002) to $23.8 \%$ in the current government. The key positions of the prime minister and the president have been held exclusively by men. Since 1996, the percentage of women in the Chamber of Deputies has varied between $15 \%$ and $22 \%$; currently there are $19.5 \%$ female Deputies. In the same period, the Senate saw an uneven progress from $11 \%$ to the current $19.8 \%$ of female Senators. Czech representation in the European Parliament currently includes $23.8 \%$ women, but the highest percentage of women is to be found in local politics; currently women constitute $27 \%$ of representatives in local assemblies. (Zastoupeni) Whereas the number of women representatives grows continuously on the local level, it fluctuates irregularly on the governmental, parliamentary and European levels.

These low percentages contrast sharply with the high rates of Czech women's education and employment (Postavení; Zaostreno). The overall low representation of women has been constantly criticized by NGOs working for gender equality, ${ }^{2}$ and the reasons for the low number of women in politics have been the subject of numerous studies by political scientists and sociologists (e.g. Saxonberg, 2003; Havelková H., 2002; Rakušanová, 2006; Rakušanová, Helšusová Václavíková, 2006; Vohlídalová et al., 2016). This paper aims to give an overview of the existing research, framing the issue of women's political representation in the context of the transition from Communism to democracy.

${ }^{1}$ This paper is an updated and expanded version of a text that was previously printed in M. Musia\}Karg, E. Lesiewicz (eds.), Women's role and their participation in public life of the Visegrad Countries, Adam Mickiewicz University, Poznan-Ústí nad Labem.

${ }^{2}$ Namely Gender Studies, o.p.s. and Forum 50\%. Forum 50\%, established in 2004, is a think-tank exclusively focussed on the issue of women and politics. Besides other activities, it produces valuable gender statistics of political representation in the Czech Republic, which are used in this paper (Zastoupeni). 


\section{Public and private: a gender perspective}

After 1989, the political representation of women was affected both by the legacy of Communism and by the new regime's efforts to establish a new identity in contrast to the Communist past. Elements of both continuity and discontinuity can be found between the old and the new regime regarding the political engagement of women. The first parliamentary elections after the Velvet revolution brought a sharp decline in the number of women elected to the parliament. Whereas under state socialism there was a $30 \%$ quota for women in the parliament (Rakušanová, 2003, pp. 1-2), after the first free parliamentary elections in 1990 the participation of women on the federal level fell to $9.6 \%$ (Havelková H., 2002, p. 83). However, this striking difference didn't mean that women's access to political power was comparable to that of men before 1989. The Communist parliament was a weak institution bereft of any real power, and the real centre of political power, the Communist Party leadership, was almost exclusively male. While evaluating the significance of those numbers, it is necessary to take into account the connotations of institutionalized politics and public sphere in general before and after 1989, the interconnections between the public and the private, and the gendered associations of the public/ private division.

The public and the private before 1989 has long been a matter of concern for a number of scholars writing about gender order under Communism. These authors, mostly sociologists writing in the 1990s and 2000s, shared similar observations concerning the devaluation of the public sphere under state socialism. Under the Communist regime, civil society was reduced to practical non-existence and the public sphere shrunk mostly to party politics and the world of work. The public sphere was often perceived as a discredited place of moral compromise, political risk and collaboration with the regime (Havelková H., 1993; Havelková H., 1995; Heitlinger, 1996; Vodochodský, 2007).

The devaluation of the public sphere went hand in hand with the increasing importance of the family. The 1970s and 1980s, commonly known as the era of "Normalisation", are sometimes characterised by political scientists as the period of the "social contract" (Civín, 2005). After the squashed attempts at reform in 1968, harsh restrictions on civic freedoms were coupled with new social benefits in order to pacify the populace, namely a generous maternity leave and various social benefits for newlyweds and young parents (Havelková B., 2014 and 2009). Citizens were expected to resign from political activity in exchange (hence the informal "social contract" between the rulers and the ruled), and to withdraw to the private sphere. In contrast to the early 1950s, the Communist regime of 1970s and 1980s mostly did not attempt to politicise the family, which was left as an avenue of tolerated escape.

The private sphere, represented by the family, gained a new value as "the only bastion of freedom" (Havelková H., 1993, p. 92) under state socialism, and is often characterized by scholars as one of the few spaces left for self-realisation, individual creativity and meaningful human interaction (Heitlinger, 1996; Havelková H., 1995; Vodochodský, 2007). It also took over some functions which are more commonly associated with the public sphere in modern societies: Hana Havelková (1993 and 1995) emphasises the family's importance for the moral education of citizens, while many authors also high- 
light its increased economic function. ${ }^{3}$ Some authors claim that many women were glad to limit their engagement in the public sphere, using their family obligations as an excuse to escape political pressure (Vodochodský, 2007).

This specifically female form of escape from unwelcome political engagement was facilitated by the ideology of separate spheres which was still persistent in Czech society under state socialism. The "Normalisation" era especially saw a reassertion of the petitbourgeois family model, although double earner family became the standard due to low wages. ${ }^{4}$ Wives were not expected to make careers, but to stay on a long maternity leave and to carry the "double burden" of housework and paid employment afterwards. ${ }^{5}$ It is true that some traditional masculine privileges had been weakened by the regime: most of the large property holders affected by expropriation were men (Wagnerová, 1995); traditional male domains such as career, private enterprise or politics itself suffered significant loss of status or were made impossible by the regime. In spite of these changes, the gender culture of state socialism remained largely conservative and many men remained directly or indirectly resistant to change (Vodochodský, 2007; Havelková H., Oates-Indruchová, 2014; Nečasová, 2008). Czech society side-stepped the discussions of Western feminist second wave; the anti-Communist dissent did not attempt to mediate such topics for Czech society or to develop an alternative gender culture. Although a significant number of women were active in the dissent, they were not interested in feminism, nor did they declare any special "women's interests" (Šiklová, 2008; Havelková H., Oates-Indruchová, 2014, p. 15).

After the Velvet revolution, the public sphere, formalized political institutions and elective political functions gained back their significance. Hand in hand with this development went the de-politicization of the private and semi-public spaces where women had been politically active as members of dissent. ${ }^{6}$ While during the Communist period the ideology of the separate spheres helped women to withdraw from the public sphere and avoid political pressure, after the Velvet revolution it constituted one of the main barriers between women and new democratic politics. The low percentage of women in political institutions is traditionally explained as the result of women's low interest in institutionalized politics. Nevertheless, the opinion polls show that women and men declare similar interest in politics, political media and civic and political participation in general (Vohlídalová, 2015). Women's aspirations to political functions are, however, obstructed by the persisting traditional family model with a long parental leave for mothers, lack of nursery schools and the double burden of employed women.

${ }^{3}$ Besides the increasing importance of family networks for access to highly demanded consumer goods or services, families were essential as units of production (Hamplová, 2010; Možný, 1999).

${ }^{4}$ For a chronologically differentiated account of gender culture in Communist Czechoslovakia see Havelková B., 2014.

${ }^{5}$ Paid maternity leave was prolonged to one year in 1969, and up to three years in 1971 (Havelková B., 2009).

${ }^{6}$ The activities of dissent, which were immensely political, had mostly taken place in the private and semi-public spaces - private apartments and living rooms of the organisers, and women had thus been a natural part of such activities as vital co-workers and co-organizers, although they were not often in leadership positions (Šiklová, 2008). 


\section{Gender roles, feminism and politics}

Under state socialism women were proclaimed as equal by the regime, and their alleged emancipation ${ }^{7}$ was used as a propaganda tool. Women's emancipation was thus presented as a goal already achieved by the Communist regime, and simultaneously it was discredited as a part of the official ideology. Moreover, gender issues like the double burden or the pay gap were mostly seen by Czech women as secondary problems compared to their oppression as citizens by the regime, an oppression they shared with men. Czech women thus tended to see their specific problems as faults of the regime, not of men, and were resistant to framing them in terms of gender discrimination (Heitlinger, 1996; Wagnerová, 2009).

The complex and contradictory heritage of Communism led to a mixed response to Western feminism or even to the mere notion of gender issues after 1989. The language of Velvet Revolution was based on the general human rights discourse and women's rights or gender inequalities were not articulated as a separate topic. Feminism was framed both as a Communist invention and a Western import, and both contradicting myths (Havelková H., Oates-Indruchová, 2014, pp. 11-17) remain surprisingly persistent in Czech society. The few emergent female politicians were reluctant to identify themselves on the basis of their gender or as feminists (Vodrážka, 1996). Many women did not see the root of their problems in discrimination or in the conservative gender order, but in "overemancipation" and an exaggerated emphasis on equality (Havelková H., 1993). The 1990s saw a cautious interest in feminism and gender by scholars and journalists, the establishment of the first feminist organization, ${ }^{8}$ but also a resurgence of conservative gender discourse, hostility towards feminism, and further entrenchment of the petit-bourgeois family model. ${ }^{9}$

The newest opinion polls show that a large segment of citizens still have conservative views on gender roles in the family. In 2013 three fifths of the respondents regarded breadwinning as men's responsibility. Opinions about childcare are more egalitarian (62\% respondents think that both partners should be involved in childcare), but $37 \%$ respondents still see it as women's responsibility (Čadová, 2014, p. 2).

Statistics also show that gender stereotypes are still present in Czech society. 36\% people think that men are better suited for top-level politics than women; this view is more widespread among men. Almost a half of male respondents held this opinion (Vohlídalová, 2015, pp. 21-23). The low number of women in politics also reinforces the widespread tendency to see the failures of female politicians not as individual failings, but rather as a proof that women in general "do not belong in politics."

While a part of the public still has prejudices against women in politics, others have an idealized vision of the female politician. $34 \%$ of respondents think that a greater

${ }^{7} \mathrm{H}$. Havelková and L. Oates-Indruchová make a convincing case for understanding the changes in women's status under state socialism as "modernization" rather than emancipation (Havelková H., Oates-Indruchová, 2014, p. 10).

${ }^{8}$ Gender Studies, o. p. s., established in 1991.

9 The 1990s saw a resurgence of the normative discourse of "intensive motherhood," the introduction of a prolonged four-year maternity leave, and the dismantling of public childcare system for children under 3 years of age. See e. g. Hašková H., Saxonberg S. (eds.), Mudrák J. (2012); Maříková H. (ed.), Kř́žková A., Vohlídalová M. (2012). 
involvement of women in politics will change politics for the better. Such expectations are connected with an idealized vision of femininity. Many respondents believe that an increased number of women in politics would bring more decency, empathy and cooperation to political life, and that women would curtail the senseless rivalry, egotism and harshness of male politicians (Vohlídalová, 2015, pp. 17-19). This idealization of women's political activity may eventually turn against female politicians, as most gender stereotypes do. If female politicians do not measure up to those high expectations, they may be seen as political failures.

\section{Parliamentary elections: the nomination process}

Members of the lower chamber of the national parliament are elected via a proportional representation system with a 5\% election clause and open candidate lists. The PR system and the election clause are in general considered to be favourable to the political advancement of women (Matland, 2005). Many studies (e. g. Saxonberg, 2003) show that in regard to the political advancement of women in the Czech Republic, the Achilles heel of the PR system is the process of nominating candidates. Even though there is a substantial number of women among the memberships of Czech political parties (Šprincová, Adamusová, 2013), women are much less often than men included in political party leaderships and placed on the top of the candidate lists for elections. While constituting candidate lists, political parties often try to balance competing interests. They need to satisfy key actors within the party, and to put together a list that would get the widest possible support from the voters at the same time (Rakušanová, 2006, p. 9). The lack of women at the top of candidate lists shows that women are not perceived as "key actors" within political parties and that the parties do not see women's presence on the list as an important motivation factor for their voters. Although the majority of opinion poll respondents (59\%) perceive the lack of women in politics as a problem (Vohlídalová, 2015, p. 10), only one fifth of them see the position of women on the candidate list as an important factor influencing their electoral choice (Vohlídalová, 2015, p. 43-44).

Another factor affecting the number of women in politics is the aloof attitude of most politicians and the public to gender quotas. The Communist regime used the high percentage of women in the parliament and the public life as an important tool of selfrepresentation, ${ }^{10}$ but after 1989 the number of female politicians ceased being important for the "image" of the political regime. The low percentage of women in elected political functions has not yet been understood by the authorities as a problem that needs to be solved. On the contrary, measures that would increase the number of women in politics are mostly perceived as something undemocratic, artificial, associated with Communism, and therefore outdated after the Velvet revolution.

${ }^{10}$ The "women's question" constituted an important element of the official ideology; for Marx and Engels women's emancipation represented the best indicator of the emancipation of the people in general (Meyer, 1985, p. 17). In the official discourse the term "women's emancipation" stood for the engagement of women in public life. The high number of female students, employees as well as politicians was supposed to show the progressiveness of the regime as such. On the level of rhetoric, women's political engagement was encouraged. 
Whereas the supporters of such measures see gender quotas as a tool to equalize the starting positions of women and men in politics, most Czech political parties, including their female politicians, perceive quotas as a distortion of free competition and discrimination in favour of women; many female politicians also declare they find quotas humiliating. Although the majority of Czechs see women's political representation as insufficient and agree that it should be actively encouraged, only $37 \%$ people support a law that would compel political parties to introduce gender balanced candidate lists (Vohlídalová, 2015 , p. 6).Until recently, voluntary quotas for candidate lists have been used only by the Green party, which employs the so-called "zipper system" and consequently has high numbers of elected female candidates. In 2015 a gender quota for candidate lists at the national and regional level was adopted by the ruling Social Democratic party. The gender-neutral measure specifies that the list has to contain at least $40 \%$ members of the under-represented sex, yet it does not specify the order of those candidates on the list. The first opportunity to observe the impact of the new quota came with the recent regional elections in autumn 2016. The statistics show that all regions but one were able to fill or exceed the quota: there were $43.11 \%$ of women on Social Democratic candidate lists in total, compared to $24.63 \%$ in the previous regional elections in 2012. However, the percentage of elected female Social Democratic candidates was lower than in the previous elections: $20.8 \%$ compared to $22.93 \%$. The quotas did not have a significant impact on the overall number of women placed on the first ten positions on candidate lists. ${ }^{11} \mathrm{On}$ the other hand, there is an almost $11 \%$ increase ${ }^{12}$ of women featured in the $11^{\text {th }}-20^{\text {th }}$ positions in 2016 compared to 2012 (Volby do zastupitelstev kraju 2012, 2016). Had the party been able to repeat its success from 2012 when even the $15^{\text {th }}-20^{\text {th }}$ candidate positions were often winnable, the number of elected female candidates would have been higher than in previous years. Only future elections will tell if the increase of female candidates in these places was a result of shifting attitudes within the party, or if expectations of low election results made these places less desirable. In any case, these elections have shown that the impact of quotas is limited without the introduction of a zipper system, especially when the party faces low election results.

In 2015, Social Democratic ministers attempted to pass a similar legislative measure introducing an obligatory $40 \%$ gender quota, including a zipper system for the first three places on candidate lists, for all Czech political parties. However, the measure did not gain support from their coalition partners in government: Christian Democrats (KDU-ČSL) and ANO. It is interesting to note that although the Christian Democratic party leadership insisted that women do not need or want quotas, the Christian Democratic women themselves had a different opinion. Their organization joined its signature to an open letter supporting the legislative introduction of quotas, signed alongside the women's organizations of the Green, Social Democratic and Communist parties. It might be that this signature signals a slow shift in attitudes of female politicians, some of whom are becoming more sensitive to gender discrimination, as shown in Vohlídalová et al., 2016.

${ }^{11}$ In 2016, there were the total of 30 female candidates placed within the first ten positions on candidate lists in all 13 regions, i. e. $23.07 \%$ of available places. In 2012 , there were 26 candidates, i. e. $20 \%$.

${ }_{12}$ In 2016, there were the total of 48 female candidates on places 11-20, as compared to 34 candidates in 2012. In both years, the distribution of female candidates among the places 11-20 was more or less even. 


\section{Conclusion}

The fall of the Communist regime brought a radical change in the significance of political institutions and elective political functions, as conventional political participation gained back its lost importance. While the number of women representatives in political institutions did not say much about women's access to political power under state socialism, in a democratic political regime the number of women in politics is something that should be taken seriously.

The low percentage of women in institutionalized politics in the Czech Republic after 1989 is the result of several interacting factors. Under state socialism, gender stereotypes and patriarchal organisation of society helped many women resist the pressure to engage in official politics and thus cooperate with the regime. In the last 25 years, though, the persisting traditional family model and gender stereotypes have been one of the main barriers to women's political advancement. Opinion surveys show that a half of male respondents think that women are less suited to top-level politics than men.

The positive influence of the proportional electoral system is significantly hindered by the nomination process in political parties, with mostly men in the role of the gatekeepers. Although the majority of Czech citizens declare they want more women in politics, only a small part of them consider the position of women on candidate lists to be an important factor influencing their electoral choice. Insufficient experience with women in politics results in the idealisation of female politicians in Czech society on one hand, and distrust in their abilities and stricter assessment of women on the other hand. Gender quotas for candidate lists have been introduced as a possible solution to this impasse by feminist NGOs, and adopted by two political parties so far. Although the topic of quotas is slowly gaining prominence in public discourse, it is still met with low acceptance both by political parties and the public.

\section{Bibliography}

Civín J. (2005), Československý komunistický režim v letech 1985-1989, “Central European Political Studies Review (CEPSR)", vol. VI, no. 2-3, pp. 207-227.

Čadová N. (2014), Názory veřejnosti na roli muže a ženy v rodině - prosinec 2013, tisková zpráva Centrum pro výzkum veřejného mínění, Sociologický ústav AV ČR, Praha, http://cvvm.soc.cas.cz/ media/com_form2content/documents/c1/a7166/f3/ov140122.pdf, 20.11.2015.

Hašková H., Saxonberg S. (eds.), Mudrák J. (2012), Péče o nejmenší. Boření mýtů, SLON, Praha.

Hamplová D. (2010), Stručné poznámky o ideových př́stupech k rodině v období socialismu, "Cahiers du CEFRES", no. 22, Česko-francouzský dialog o dějinách evropské rodiny, pp. 2-8.

Havelková B. (2009), Genderová rovnost v obdobi socialismu, in: M. Bobek et al., Komunistické právo $v$ Československu. Kapitoly z dějin bezpráví, Mezinárodní politologický ústav, Masarykova univerzita, Brno, pp. 179-206.

Havelková B. (2014), The Three Stages of Gender in Law, in: H. Havelková, L. Oates-Indruchová, The Politics of Gender Culture under State Socialism. An Expropriated Voice, Routledge, LondonNew York, pp. 31-56.

Havelková H. (1993), „Patriarchy” in Czech society, “Hypatia”, vol. 8, no. 4, pp. 89-96.

Havelková H. (1995), Dimenze ,,gender” ve vztahu soukromé a veřejné sféry, "Sociologický časopis", vol. 31 , no. 1, pp. 25-38. 
Havelková H. (2002), Politická reprezentace žen v České republice, in: Hlasy žien. Aspekty ženskej politiky, eds. J. Cviková, J. Juránová, Aspekt, Bratislava, pp. 82-100.

Rakušanová P. (2003), Ženy v politice a postoje veřejnosti, "Naše společnost”, vol. 1 no. 1-2, pp. 25-28.

Havelková H. Oates-Indruchová L. (2014), Expropriated Voice: transformations of gender culture under state socialism; Czech society, 1948-89, in: H. Havelková, L. Oates-Indruchová, The Politics of Gender Culture under State Socialism. An Expropriated Voice, Routledge, London-New York, pp. 3-27.

Heitlinger A. (1996), Framing Feminism in Post-Communist Czech Republic, "Communist and PostCommunist Studies", vol. 29, no. 1, pp. 77-93.

Matland R. E. (2005), Enhancing Women's Political Participation: Legislative Recruitment and Electoral Systems, in: Women in Parliament: Beyond Numbers, eds. J. Ballington, A. Karam, International Institute for Democracy and Electoral Assistance (IDEA), Stockholm, pp. 93-111.

Maříková H. (ed.), Křížková A., Vohlídalová M. (2012), Živitelé a živitelky: reflexe (a) praxe, SLON, Praha.

Meyer A. G. (1985), Feminism, Socialism, and Nationalism in Eastern Europe, in: S. L. Wolchik, A. G. Meyer, Women, State, and Party in Eastern Europe, Duke University Press, Durham, pp. 13-30.

Možný I. (1999), Proč tak snadno... Některé rodinné di̊vody sametové revoluce. Sociologický esej, SLON, Praha.

Nečasová D. (2008), Nadčasové stereotypy o ženách v politice, in: 19. století v nás: modely, instituce a reprezentace, které pretrvaly, ed. M. Řepa, Historický ústav AV ČR, Praha, pp. 483-490.

Nečasová D. (2014), Veřejná sféra a genderová analýza po únoru 1948: přispěvek do diskuze, "Studia Historica Nitriensia", vol. 18, no. 1, pp. 62-75.

Postavení žen v české vědě. Monitorovaci zpráva za rok 2014 (2015), Sociologický ústav AV ČR, http:// www.genderaveda.cz/files/postaveni-zen-v-ceske-vede-2014-web.pdf, 10.12.2016.

Rakušanová P., Helšusová Václavíková L. (2006), Ženy v mužské politice, in: Mnohohlasem. Mapování prožensky orientovaných aktivit po roce 1989, eds. H. Hašková, A. Kř́žzová, M. Linková, Sociologický ústav AV ČR, Praha, pp. 43-59.

Saxonberg S. (2003), Czech Political Parties Prefer Male Candidates to Female Votes, in: Women's Access to Political Power in Post-Communist Europe, eds. R. E. Matland, K. A. Montgomery, Oxford University Press.

Šiklová J. (2008), Podil českých žen na samizdatu a v disentu v Československu v obdobi tzv. normalizace v letech 1969-1989, "Gender, rovné př́ležitosti, výzkum”, vol. 9, no. 1.

Šprincová V., Adamusová M. (2014), Politická angažovanost žen v České republice. Přehledová studie 1993-2013, Fórum 50\%, Praha, http://aa.ecn.cz/img_upload/666f72756d35302d66693130303 13139/politicka-angazovanost-zen-v-ceske-republice_forum_1.pdf, 10.12.2016.

Vodochodský I. (2007), Patriarchát na socialistický způsob: K genderovému řádu státního socialismu, "Gender, rovné př́ležitosti, výzkum", vol. 8 , no. 2.

Vodrážka M. (1996), Feministické rozhovory o "tajných službách”, Gender Studies, Praha.

Vohlídalová M. (2015), Výzkumná zpráva z dotazníkového šetřeni „Ženy a muži v rovnováze”, Sociologický ústav AV ČR, Praha, http://aa.ecn.cz/img_upload/666f72756d35302d6669313030313139/ vyzkumna-zprava-z-dotaznikoveho-setreni_postoje-verejnosti-k-pusobeni-zen-v-politice.pdf, 20.11.2015.

Vohlídalová M., Maříková H., Čermáková M., Volejníčková R. (2016), Sólo pro soprán. O ženách $v$ české politice, Sociologický ústav AV ČR, Praha, http://www.soc.cas.cz/sites/default/files/ soubory/solo_pro_sopran_na_web_soc.cas_0.pdf, 10.12.2016.

Volby do zastupitelstev krajů konané dne 12.10.-13.10.2012, Czech Statistical Office, http://www. volby.cz/pls/kz2012/kz?xjazyk=CZ\&xdatum=20121012, 10.12.2016. 
Volby do zastupitelstev krajü konané dne 7.10.-8.10.2016, Czech Statistical Office, http://www.volby. $\mathrm{cz} / \mathrm{pls} / \mathrm{kz2016} / \mathrm{kz}$ ?xjazyk=CZ\&xdatum=20161007, 10.12.2016.

Wagnerová A. (1995), Emancipace a vlastnictví, “Sociologický časopis”, vol. 31, no. 1, pp. 77-84.

Wagnerová A. (2009), Co přinesl a co nepřinesl českým ženám socialistický model rovnoprávnosti - aneb nejen jesle a traktoristky, in: Gender a demokracie 1989-2009, ed. L. Sokačová, Gender Studies, Praha, pp. 11-19.

Zaostřeno na ženy a muže 2015. Práce a mzdy, Czech Statistical Office, https://www.czso.cz/csu/ czso/4-prace-a-mzdy, 10.12.2016.

Zastoupení žen a mužů v politice, Forum 50\%, http://padesatprocent.cz/cz/statistiky/zastoupeni-zen-amuzu-v-politice, 10.12.2016.

\section{Reprezentacja polityczna kobiet w Republice Czeskiej, w kontekście przejścia od komunizmu do demokracji}

\section{Streszczenie}

W artykule przedstawiony został przegląd reprezentacji politycznej kobiet w Czechosłowacji oraz w Czechach po upadku żelaznej kurtyny, w kontekście przejścia od systemu komunistycznego do demokracji. Artykuł obejmuje rozważania zarówno dotyczące ciągłości i zmiany, pomiędzy starym a nowym systemem, skupiając uwagę na zaangażowaniu politycznym kobiet - począwszy od utrzymywania tradycyjnego modelu rodziny i stereotypów płciowych, a kończąc na radykalnych zmianach ról w sferze prywatnej i publicznej. Koncentrując się na mechanizmach blokujących kobiety w ich dostępie do władzy politycznej i postawach społecznych, które mogłyby wyrównać ostatecznie szanse, a mianowicie zastosowaniu parytetów płciowych na listach wyborczych partii politycznych.

Słowa kluczowe: kobiety, partycypacja polityczna, gender, parytety, wybory, komunizm, Republika Czeska 
